\title{
Employment of Ex-Drug Addicts as a Corporate Social Responsibility Initiative: The Malaysian Employer's Perspective
}

\author{
Jamilah Ahmad \\ School of Communication, Universiti Sains Malaysia (USM) Pulau Pinang, Malaysia \\ Fauziah Md. Taib \\ School of Management, Universiti Sains Malaysia (USM), Pulau Pinang, Malaysia \\ Amin Jan (Corresponding Author) \\ Faculty of Hospitality, Tourism and Wellness. Universiti Malaysia Kelantan, City Campus, \\ Pengkalan Chepa, 16100, Malaysia. E-mail: amin_khan@yahoo.com
}

Received: August 5, 2021

Accepted: August 20, 2021

Published: August 23, 2021

doi:10.5296/jebi.v8i2.18956 URL: http://dx.doi.org/10.5296/jebi.v8i2.18956

\begin{abstract}
Relapse together with stigma and perceptions are serious challenges that need to be addressed promptly. Past literature is with the view that the issue of relapse occurs due to several stressors, including unemployment. Scant frameworks exist on the strategic development that promotes the employment of ex-drug addicts to reduce the relapse rate. In the same vein, this study seeks to discover the misperception and stigma surrounding the employment of ex-drug addicts in Malaysia as well as to explore employers' views in hiring those ex-drug addicts as part of the Corporate Social Responsibility (CSR) initiative. This study is consistent with qualitative research based on interviews with eight Malaysian employers. This study found that the hiring of ex-drug addicts as a part of the company's CSR initiatives may $(a)$ reduce the relapses of drug addicts $(b)$, it will uplift the CSR ratings of the subjected companies and (c), it will increase the compliance of the companies with Sustainable Development Goals through the subjected CSR initiatives. In line with that, this study proposed a novel strategic framework by aligning the subjected CSR initiative with social sustainability and subsequently to Sustainable Development Goals. The proposed strategic framework will insight policymakers and employers into contributing to sustainable development through hiring ex-drug addicts.
\end{abstract}


Keywords: Ex-Drug Addicts; Corporate Social Responsibility; Sustainable Development Goals; Malaysian Employers

\section{Highlights:}

- $\quad$ Proposed the "employment of ex-drug addicts as a vital CSR initiative

- $\quad$ Proposed strategic framework for categorisation and alignment of "employing ex-drug addicts" with social sustainability and sustainable development goals

- $\quad$ Provided managerial view and willingness in employing ex-drug addicts

\section{Introduction}

The world is recurrently facing extreme social challenges of high impact (Jan et al., 2021). Social challenges include extreme human rights violation, child labour, forced labour, large scale involuntary migration, human trafficking, gender equality, and rehabilitation of ex-drug addicts, among others (Potrikeeva et al., 2017). Responding to those global challenges, the United Nations (UN) launched 17 Sustainable Development Goals (SDGs) in 2015 (Jan, Marimuthu, \& Hassan, 2019). The SDGs are considered as the blueprint for a better future and sustainable development involving all stakeholders (Pradhan, Costa, Rybski, Lucht, \& Kropp, 2017). Many businesses worldwide, linked their business policies and business models with the greater SDGs framework as a Corporate Social Responsibility (CSR) (Jan, Marimuthu, \& Hassan, 2019). CSR is referred to as the company's self-regulated activities aimed at mitigating social issues (Khan, Khan, Ahmed, \& Ali, 2012). The drug is considered one of the major social issues (F Ali et al., 2011). It is a perpetually relapsing disorder marked by compulsive use of addictive drugs despite negative repercussions for the individual and society (Koob \& Volkow, 2010).

Malaysia's epidemic of substance abuse and addiction is viewed as a serious and unending crisis (Mohd \& Kamarulzaman, 2016). The government declared drugs as the number one enemy in the country on 19 February 1983 due to the drug issue that become extremely violent and posed a national security threat (Sadiron, 2015). Apart from that, in the same year 1983, the drug dependents (treatment and rehabilitation) act was introduced, and a one-stop centre named Pusat Serenti was formed. The declaration of the drug as the number one enemy in Malaysia for over three decades indicates a strong view on the part of the government that this issue constitutes a danger to national security. Surprisingly about 40-60 percent of recovering drug addicts' relapse, these repeated levels are close to those of other chronic illnesses such as high blood pressure and asthma (Lian \& Chu, 2013). This shows that relapse cases among drug addicts in Malaysia are a serious issue (Adam, Ahmad, \& Fatah, 2011).

A relapse won't happen without a stressor, unable to get employment after release, plus lack of financial assistance for survival has led ex-drug addicts to revert to their old habit. Fauziah et al. (2011), conducted a study on 400 rehabilitees from eight narcotics addiction recovery centres in Peninsular Malaysia and found that their previous employers did not grant 61.5 percent of respondents a second chance. The social stigma which treats ex-criminals as those 
with deficits in character applies to those with marks on their criminal history, give them nothing more than a slim opportunity (Zakaria, Jaafar, \& Lazim, 2018). To reduce relapse, it is vital to provide financial assistance to the subjected person once they are free. The unemployment issue among ex-drug addicts will victimise former offenders, particularly the young people who want to rebuild their future. Regarding the case of unemployment among ex-drug addicts, Walton and Hall (2016), illuminated that possession of a job is an aim for many people to rebound from drug use and guard against recurrence. For people recovering from drug use disorders, getting hired is useful for the aforementioned reason and essential for sustained rehabilitation. Jobs allow people to learn to withhold pleasure and to handle disappointment and other negative emotions in a good way, providing them with a sense of accomplishment. In consonant with the above issues, the main objectives of this study are to understand Malaysian's employer's view on hiring ex-drug addicts as a part of their CSR initiatives. To what extent employers are willing to employ ex-drug addicts? And what is the motivation for employers in hiring them? To answer these questions the main objectives of the study are,

- $\quad$ To understand employers' view in hiring ex-drug addicts as part of the CSR initiative.

- To what extent employers are willing to help ex-drug addicts as part of their CSR initiatives

Achievement of these objectives will $(a)$ reduce the relapses of drug addicts in Malaysia $(b)$, it will uplift the CSR ratings of the subjected companies and (c), it will increase the compliance of the companies with Sustainable Development Goals SDGs through the subjected CSR initiatives.

The structure of the remaining paper is as follows. The following section explains the literature revive including theoretical foundation and conceptual framework. It is followed by the methodology, findings and subsequent discussion. The last part of this paper discusses the conclusion and policy implications.

\section{Literature Review}

This study is motivated in understanding the employer's perspective in hiring ex-drug addicts as part of their CSR initiatives. The following section explains the theoretical foundation, proposition development, and conceptual framework in the same vein.

\subsection{Theoretical Foundation: The Stakeholders Theory}

Stakeholder theory considers persons and entities as the stakeholders of the firm. The stakeholder theory, attributed to R.E. Freeman (1984), argues that an enterprise is not an 'island': it does not function in isolation, its operations extend beyond the equity holders to embrace any person or group in society that influences, or is affected by, its activities (Waheed \& Zhang, 2020). The theory posits that managers must strive to satisfy diverse stakeholders (such as employees, customers, suppliers, investors, agencies, governments, regulatory bodies, and the public) who can direct or indirectly influence what the firm does (Kamal, 2021). The stakeholders' theory suggests that companies should not only work for 


\section{Macrothink}

their investors, but they should also work for the benefits of all the other stakeholders (Mazur, Cichorzewska, \& Mazur-Małek, 2020). There are so many personal values, which should be made part of the firm's strategy, such as following ethical guidelines to develop a better relationship, such as following ethical guidelines to develop a better relationship between the stakeholders and the firms (R Edward Freeman, Wicks, \& Parmar, 2004). Moreover, suppose managers work prudently to make their firms more transparent. In that case, it is more likely that the stakeholders will regard their CSR commitment to be genuine and predictable and further strengthen good company relationships. Managers always seek support from the stakeholders and employ transparent communications strategies to retain an interest in the company. A poor level of transparency could lead to doubts about the future of the company and may lead to sceptical shareholders (Dexe, Franke, \& Rad, 2021). Based on the stakeholders' theory insights, Malaysian employers should hire ex-drug addicts as a CSR activity. It will reduce the social challenges faced by Malaysia in terms of the subjected drug addicts. At the company's end, it will improve its CSR ratings, and the higher CSR rating offers the companies to apply for more funding. Therefore, along with solving the social issue, adoption of CSR practices by the companies will improve their financial performance as well (Jan \& Marimuthu, 2015; Jan, Marimuthu, bin Mohd, \& Isa, 2019; Jan, Marimuthu, \& Hassan, 2019; Jan, Marimuthu, Pisol, Isa, \& Albinsson, 2018). The stakeholders' theory alludes to addressing three main groups of stakeholders (economic, environmental and social). It is also sometimes referred to as the Triple Bottom Line TPL (people, planet and profit) (Elkington, 1998). The theoretical foundation of this study is depicted in Figure 1 below.

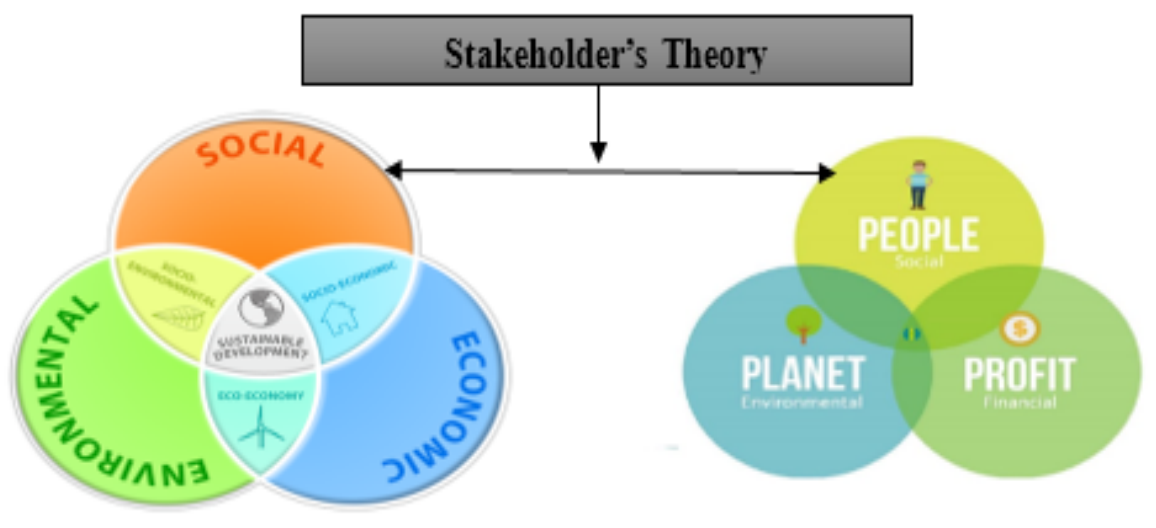

Figure 1. Theoretical Foundation

Figure 1 shows the theoretical foundation of this study, and it shows that in line with the stakeholder's theory, this study aims at addressing social sustainability (people). This study extends that it's the social responsibility of Malaysian employers to hire ex-drug addicts. Grounded with the stakeholders' theory, the subject hiring will ensure the corporate social responsibility of Malaysian employers and will mitigate the problems faced by ex-drugs addicts after their recovery.

\subsection{Proposition Development}

The following sections explain about development of propositions in the context of the 
stakeholders' theory.

\subsubsection{Stigma and Perception in Hiring Ex-Drug Addicts as Part of CSR Initiative}

Three misperceptions have been outlined by the National Anti-Drugs Agency (NADA) in regards to the issues of drug addicts in Malaysia. (1) Drug addicts have no hope of recovery, (2) drug addicts always be likened to criminals, and (3) the problem is not a community problem but a drug addict's problem (NADA, 2015). By having such misperceptions, it is hard for ex-drug addicts to even survive in society. Concerning employment, 130478 drug addicts identified by occupation are registered between 2014 and 2018 in Malaysia. Of the total number of part-time employees, 38,174 (29.26\% of all drug addicts) are registered addicts are from general workers. Only $14.56 \%$ of total drug addicts are unemployed, which indicate that most drug addicts have basic skills either in technical or non-technical work. This data demonstrates that skills are not a problem, but other factors may contribute more to employers' reluctance for employing ex-drug addicts. This supports the above argument that stigma and perception have overshadowed the work skills they possessed.

Table 1. Number of drug cases identified by occupation in the year 2014-2018

\begin{tabular}{lllllll}
\hline State/ Year & $\mathbf{2 0 1 4}$ & $\mathbf{2 0 1 5}$ & $\mathbf{2 0 1 6}$ & $\mathbf{2 0 1 7}$ & $\mathbf{2 0 1 8}$ & Total \\
\hline Construction & 606 & 531 & 453 & 297 & 303 & 2,190 \\
General Workers & 4,805 & 5,086 & 5,232 & 5,416 & 5,621 & 26,160 \\
Entertainment & 37 & 48 & 27 & 41 & 19 & 172 \\
Sales & 1,837 & 2,061 & 2,101 & 1,708 & 1,607 & 9,314 \\
Unemployed & 2,746 & 3,911 & 4,533 & 4,125 & 3,650 & 18,965 \\
Transportation & 1,144 & 1,245 & 1,230 & 950 & 940 & 5,509 \\
Management* & 179 & 199 & 215 & 247 & 207 & 1,047 \\
Student & 97 & 269 & 298 & 281 & 186 & 1,131 \\
Clerical & 51 & 52 & 66 & 66 & 58 & 293 \\
Services & 2,460 & 2,348 & 2,299 & 1,744 & 1,822 & 10,673 \\
Manufacturing & 502 & 522 & 576 & 465 & 421 & 2,486 \\
Agriculture \& Fisheries & 1,814 & 1,969 & 1,857 & 1,443 & 1,457 & 8,540 \\
Part Time Workers & 4,155 & 7,117 & 10,643 & 8,173 & 8,086 & 38,174 \\
Technical & 1,244 & 1,310 & 1,314 & 966 & 890 & 5,724 \\
Total case & 21,777 & 26,668 & 30,844 & 25,922 & 25,267 & 130,478 \\
\hline
\end{tabular}

Source: National Anti-Drug Agency (National Anti-Drugs Agency [NADA]. (2015). Pelan Strategik Agensi Antidadah Kebangsaan $\quad$ (AADK) $2015-2020 . \quad$ Retrieved from https://www.adk.gov.my/wpcontent/uploads/Buku_Pelan_Strategik_Updated9. Pdf)

According to Hoffmann and Larison (1999), the reluctance of employers to hire ex-drug addicts is regard as fears that they tend to create a harmful culture of drug abuse in the workplace (Fauziah et al., 2011). Holzer, Raphael, and Stoll (2001) argued that more than 60 
per cent of employers expressed that they will possibly not' or 'surely not' be willing to hire a criminal applicant. In contrast, 38 per cent of employers state that they "should possibly" or "potentially" consider a convicted candidate. Only 12.5 per cent of which would likely consider employing ex-offenders. Employers are generally reluctant to employ a risky candidate. They are concerned about whether a person is "fit for the job" in terms of reliability, capability, and timeliness. Fauziah et al. (2011) indicated that about 78.5 per cent of respondents recognise that many employers have no faith in former drug addicts, even though they know they have technical capabilities. Against that background, the following hypothesis is developed.

P1: Employers show negative perception and reluctance for employing ex-drug addicts due to hesitation in having ex-drug addicts working in the organisation.

\subsubsection{Employment-Based Interventions and Willingness to Hire Ex-Drug User}

The world business council for sustainable development describes CSR as a relentless commitment to be moral while improving the quality of living for workers, their families, the surrounding environment and society in general (Watts \& Holme, 1999). Abd Rahim, Jalaludin, and Tajuddin (2011) explained CSR as a philosophy in which organisations take responsibility for the effect of their actions on members as well as the environment and represent the interest of society. This responsibility goes beyond the legal duty and includes companies taking voluntary incremental steps to enhance the quality of life of their employees and families and the local community and culture. Research shows that people who engage in job programmes have reduced the usage of a substance by nearly half the rate compared to individuals who have not been offered employment (Silverman et al., 2002). Relevant outcomes were found in various types of drugs used, with studies showing alcohol, marijuana, cocaine, opiate, and polysubstance reduction (Greenwald, 2010). Leukefeld, Webster, Staton-Tindall, and Duvall (2007), reported that the study period saw less substance use on participants who improved the quality of their employment (i.e. increased salary, more interesting work) than those with lesser quality jobs.

Walton and Hall (2016), revealed that employment intervention has generally been effective in decreasing drug use. Having stable jobs provides access to income that can be spent on securing accommodation, correlating with better mental and physical wellbeing. Aside from that, their study described two dominant approaches: one considers employment as a criterion for an effective rebound while another area aims to see if being employed can be considered a treatment itself. The employment-based abstinence reinforcement method also seems to be supported by (Silverman, Holtyn, \& Morrison, 2016). Their study shows that having jobs alone are not enough to encourage sustained abstinence. The research indicates that chronic drug users will likely consume drugs even they have a job but tend to stay abstinent if required as a working condition or impacting their pay check. Even though the ex-drug addicts are employed, a consistent check-up is crucial to ensure they stay abstinent and on medications if required. Based on this seriousness and complications the employers are reluctant to hire ex-drug addicts. Against that background, the following propositions are developed. 


\section{Macrothink}

P2: Employers are willing to hire ex-drug addicts subjected to higher authority instruction

\section{Conceptual Framework}

In the context of theoretical foundation and proposition development, the subsequent section shows the conceptual framework of this study in Figure 2 below.
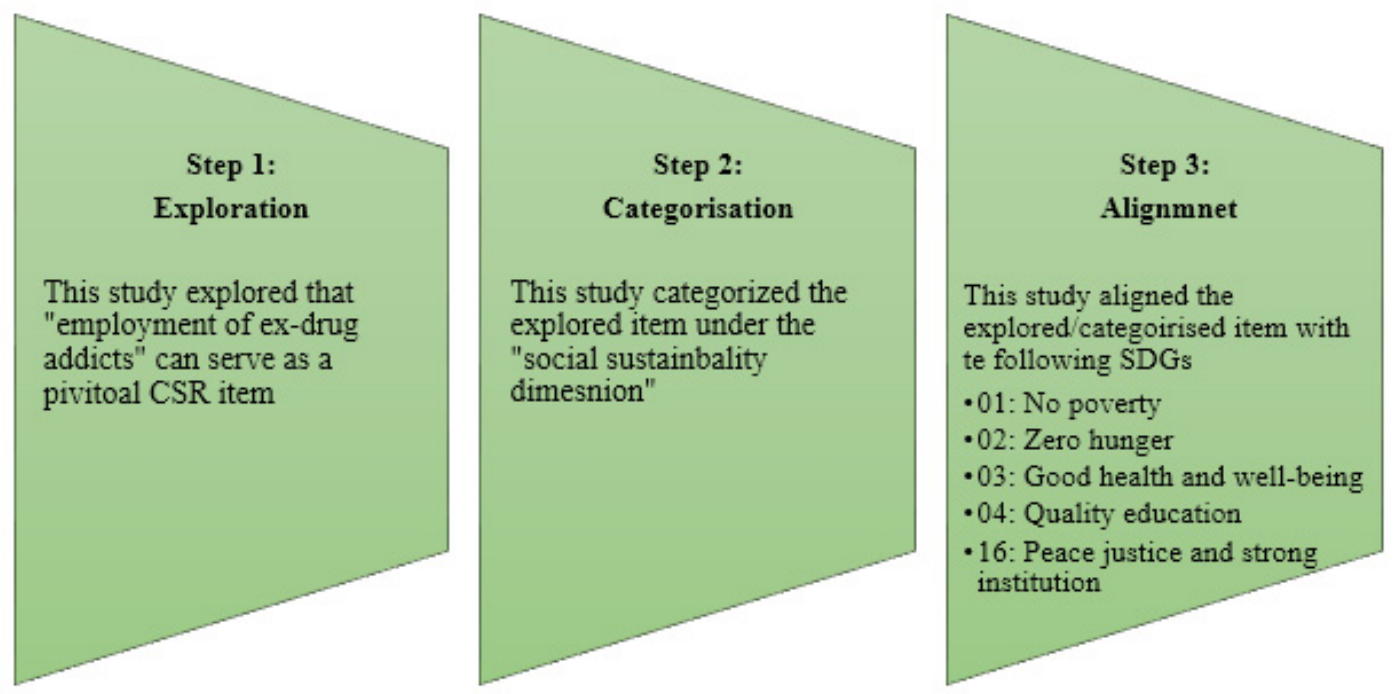

Figure 2. Conceptual Framework of this study (Graphical Abstract) Based on the ECA-Method

This study proposes a new three-step framework for the employment of ex-drug addicts in line with the ECA method (Exploration, Categorisation and Alignment). The ECA method was developed by Jan et al. (2021), for the alignment of sustainable business practices with Sustainable Development Goals. The ECA method allows a company to streamline its sustainability practices and to increase its compliance with the SDGs. The steps in the proposed framework as per the ECA method are explained below.

\subsection{Step 1: Exploration}

The ECA-methods at the first step posits to explore vital sustainability items or strategy. In line with the central concept, this study, during the exploration stage, founds that the employment of ex-drug addicts can serve CSR initiatives. It is because, based on the CSR philosophy, it is the social responsibility of firms to comply with deprived stakeholders in society. The ex-drug addicts, if not embraced properly by society, can easily relapse. Therefore, as a social responsibility, the firm's must hire those ex-drugs addicts who are fully recovered. The subjected employment will increase CSR ratings of firms', and therefore it is affirmed that the hiring of ex-drug addicts can serve as a pivotal CSR item.

\subsection{Categorisation}

As per the ECA method, the categorisation step involves an axial coding paradigm for 
categorising explored/shortlisted CSR items with a broader category. Based on the axial coding paradigm (refer to appendix Table A), this study categorised the CSR item of "employing ex-drug addicts" under the social sustainability dimension. This study anticipates that the subjected categorisation will insights the managers that the subjected employment of ex-drug addicts will improve their firm's social sustainability. Once they are illuminated that the subject hiring will enhance the social category of sustainability, the managers will work with further clarity and confidence in hiring them. It is because many managers would be reluctant to hire ex-drug addicts until there is a clear and concrete impact on their businesses. With such categorisation and positive impact, it would become easier for the managers to enact for the employment of ex-drugs addicts in their business strategic framework. The overall transformation will improve the social sustainability ratings of those firm which hires ex-drug addicts.

\subsection{Alignment}

The third stage of the ECA method posits to align the categorised CSR strategy with Sustainable Development Goals SDGs. It offers firms to attain greater international recognition by ensuring valuable compliance. This study based on the axial coding paradigm (refer to appendix Table A) made the alignment of the categorised sustainability items with SDGs (01, 02,03,04,05 and 16). It is because as per (Jan et al., 2021), these SDGs are purely related to social sustainability. Further, this study anticipates that the hiring of ex-drug addicts will ensure their financial needs, which will reduce their poverty level and as a subset they would be able to pay for their food, health and education. These transformations will promote peace and justice in society and will eventually provide the base for a more stringer institution. After the detailed explanation of the proposed framework, the following section explains the methodology in detail.

\section{Methodology}

The step by step methodological process of the study is explained below.

\subsection{Measures and Scales}

This research applied a qualitative research design to answer the research objectives, particularly an in-depth interview method to collect findings on the research study. In-depth interviews have been described by Boyce and Neale (2006), as a qualitative research methodology, involving intensive individual discussions with a small number of respondents to find out about a specific idea, programme, or issue. A detailed interview with a framework that is open-ended and discovery-oriented will help to explain both the programme mechanism and the findings from the interviewee perspective (Daymon \& Holloway, 2010). The goal is to deeply understand the viewpoint, feelings and experiences of the respondent in greater detail.

\subsection{Sample of Study and Data Collection}

This study collected qualitative data based on interviews involving respondents from eight organisations across the business sectors (refer to Table 2). The selected companies are 


\section{Macrothink}

comprised of two sects $(a)$ those businesses which have the experience of employing ex-drug addicts and $(b)$ those businesses which do not have experience of hiring ex-drug addicts. These diverse sample sets will illuminate the experience of those employers who have already employed ex-drugs addicts as well as those employers who do not employ them yet. It is to understand what fears do they have and how and what strategies will minimise them. The sampled respondents belong to the following four categories public relations officer, a communication manager, a senior public practitioner, or a chief executive officer.

Table 2. List of Respondent

\begin{tabular}{lll}
\hline Respondent & Business Nature & Type of Company \\
\hline R1 & A diversified group with six core businesses namely plantation, & \\
& property investment \& development, credit financing, automotive, Public-listed \\
& trading and building materials. & \\
R2 & An independent water and power producer with a core focus on power & Public-listed \\
& generation, water desalination and operation \& maintenance services. & \\
R3 & Fertiliser management, plantation work contract, the supply of & Government-linked \\
R4 & agrochemical products and varied businesses. & \\
R5 & The City council administers the city of Kuala Lumpur. & Government-linked \\
R6 & The world largest casual theme restaurant chain specialising in ribs. & Private \\
& Provision of maintenance services for locomotives and their related & Private \\
services. & $\begin{array}{l}\text { The agency under the Ministry of Finance Malaysia functions to } \\
\text { facilitate the overall development of the Malaysian healthcare travel }\end{array}$ & Government-linked \\
& industry. & \\
The agency under the Ministry of Rural and Regional Development & \\
& was formed to aid, train, and guide Bumiputra (Malays and other & Government-linked \\
& indigenous Malaysians) in the areas of business and industry. & \\
\hline
\end{tabular}

\section{Analysis and Results}

The data analysis and results are explained in detail below.

\subsection{Stages of Conducting an In-depth Interview for This Study}

Kvale (1996), identifies seven phases of in-depth interviews. The stepwise stages are thematizing, designing, interviewing, transcribing, analysing, verifying, and reporting. 


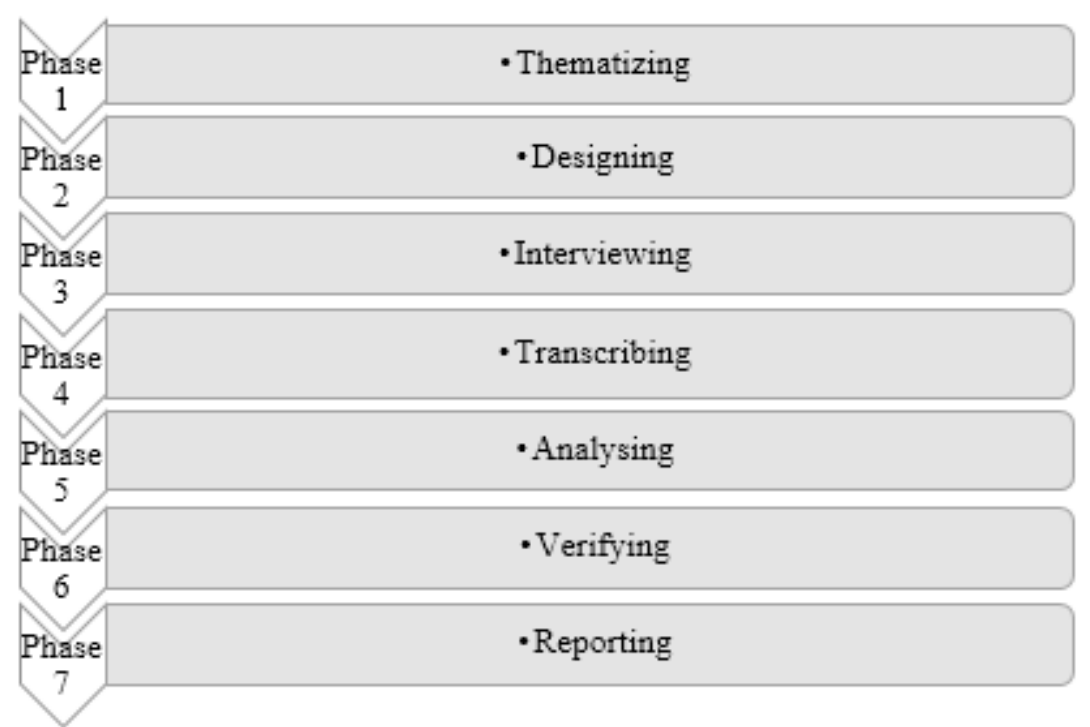

Figure 3. Phases of In-depth Interview

This study conducted in-depth interviews with 8 respondents from three business sectors i.e. (government-linked, public listed and private companies). Four interviews were conducted face to face while the remaining were conducted via email interviews. All respondents were public relations practitioners except one who was the director of an organisation. This study followed the following steps for collecting and subsequent data analysis.

\subsubsection{Phase 1: Thematizing}

This phase clarifies the purpose of the interview. During this phase, this study designed the themes of the in-depth interview to assess needs across the respondents.

\subsubsection{Phase 2: Designing}

This phase deals with formalised information-gathering strategies around the key area of research. This study designed open-ended questions during this phase.

\subsubsection{Phase 3: Interviewing}

This phase posits to first explain the research topic carefully to make the respondent feel comfortable and fully aware of the interview agenda. In line with that this study first explained the purpose of this research to all the respondents carefully and after posting questions carefully observed their responses until all the questions were covered in the interview.

\subsubsection{Phase 4: Transcribing}

For each interview, transcribing involves making a verbatim text by writing each question and replaying it with an audio recording. The interview side notes must also be documented and appropriately labelled in a different column or category. In line with that, this study carefully transcribes the responses in a written form. 


\section{Macrothink}

\subsubsection{Phase 5: Analysing}

Analysing involves reading the interview transcript to identify themes emerging from the respondents. Theme and questions should be used to evaluate and synthesise the solutions to the questions raised. This study found during the analysing phase that most of the answers are related to the social sustainability dimension.

\subsubsection{Phase 6: Verifying}

The verification process involves validating the credibility of the information gathered and a triangulation method is commonly used to achieve this goal. Triangulation requires the perception from different viewpoints of a single set of an answer. An easier way of using triangulation in a study is through reading and reviewing the same set of transcripts and comparing reports by two colleagues. In line with that, this study sent out the transcription of data to senior professors at the department and little modification was incorporated in the collected data.

\subsubsection{Phase 7: Reporting}

Finally, the outcomes of the detailed discussions will be shared in a written or oral report with both internal and external stakeholders. A good report will not only clarify the findings, but also the effects on future studies. This study presents the reporting on fining in the following section in detail.

\subsection{Results and Policy Insights}

The results from the interview were collected and re-organised using the tabulation method following the sequence of interview questions and groups according to research questions for better understanding. This section presents the tabulation of all the data used in this study. A sample of eight companies was used, which led to five types of business industries. Results on nine themes of the interviews are presented in Table 3 below. 
Table 3. Managerial Based-View Results and Policy Insights

Themes

1. CSR in creating value and solving social issues

2. Inclusion of employing ex-drug addicts in the company's CSR reporting

3. Perception of hiring ex-drug addicts as CSR initiative

4. Employer's confidence in having ex-drug addicts as their employee

5. Perception of inclusive approach (hiring/helping) ex-drug addicts to minimise the risks and facilitate the reduction in illicit substance use

6. Company/organisation and employees willing to help ex-drug addicts

7. Kind of offers by the company to help ex-drug addicts

8. Factors that contribute to the unemployment of ex-drug addicts

\section{Policy Insights}

Out of the sample, 87.5 per cent of managers believes that CSR practices solve social problems. While 12.5 per cent don't think that CSR solves social problems.

Sixty-seven per cent of managers agree $t$ that employing ex-drug addicts should be included in CSR reporting, with 33 per cent of managers thinking the other way.

Seventy-five per cent of managers possess a positive perception of hiring ex-drug addicts, while 12.5 per cent of managers possess a negative view. While the remaining 12.5 per cent remained neutral.

Twenty-five per cent of managers expressed their full confidence in hiring ex-drugs addicts, while 25 per cent showed no confidence in hiring ex-drug addicts. On the other hand, 50 per cent of managers gave a neutral opinion.

87.5 per cent of managers believe that an inclusive approach will help to reduce the risk of drug abuse. At the same time, 12.5 per cent of managers believe the other way.

One hundred per cent of managers were found willing to help ex-drug addicts. However, $25 \%$ of them argued that they do not have any policy guidelines on it. They further expressed that they would like to see such policies in their companies as well.

75 per cent of the managers alluded that they would only hire those ex-drug addicts with experience related to the job need, but they expressed that they can provide free training to them. Twenty-five per cent of managers would offer internship based offers to ex-drug addicts.

62.5 per cent of managers consider stigma associated with violence to be the main factor with refrains managers to hire ex-drug addicts. 12.5 per cent of managers believe that it will affect company image and its branding. 12.5 per cent believes that it requires extra observation and extra cost. In contrast, the remaining 12.5 per cent of managers believe that they do not have any human development policy to hire them.
It insights practitioners for (commencing) and government agencies for (enacting) CSR practices in Malaysia towards solving social issues

It is in sighting policymakers involved in designing CSR reporting frameworks such as Bursa Malaya's (suitability tool-kit) etc.

It insights practitioners for (commencing) and government agencies for (enacting) policies towards hiring ex-drug addicts as CSR initiative

In-sighting policymakers to develop a framework by explaining a detailed recruitment process to bring organisational clarity in hiring ex-drug addicts.

The hiring/helping strategy provides an opportunity to the practitioners to mitigate social risks by exercising corporate social roles.

It is leading the practitioners and government towards developing a central framework by intergrading hiring of ex-drug addicts as a CSR strategy

It is in sighting government bodies to propose employment training schemes. As most of the managers are reluctant to hire them without proper training.

It insights the government bodies to provide proper training and good character certificates following the training to increase the trust of employers in them.

insights practitioners to 
consideration from management there is no such policy implemented in in hiring ex-drug addicts

10. Driving factor that influences the company to hire ex-drug addicts as CSR initiative

11. How law, social support or moral obligation motivate organisations in hiring ex-drug addicts as part of CSR their organisation. 12.5 managers alluded that they have active policies in hiring ex-drug addicts. 12.5 per cent of managers believe that currently, there is no need to hire them. In comparison, the remaining 25 per cent of managers, argued that they have not yet hired ex-drug addicts, but they are interested in designing policies for it.

37.5 per cent of managers believe that the government policy on tax exemption is a great motivator in hiring ex-drugs addicts as a CSR initiative.12.5 managers' believers' sympathy is one of the main motivators hiring them. 12.5 per cent of managers believe that it improves the goodwill of the firm. 12.5 managers disagree with the notion and alluded that hiring them is not part of CSR, therefore no motivation to hire them.

Twenty-five per cent of managers believes that law enforced by the government can support the hiring of ex-drugs addicts as part of CSR activities. 12.5 managers believe it as a moral obligation. 12.5 managers believe that clients' pressure motivates companies in hiring them. 12.5 managers argued that it is wrong to categorised hiring ex-drug addicts as a CSR initiative. Rewarding the system to companies on hiring them will motivate the hiring of ex-drug addicts. While the remaining 12.5 managers believe that an integrated collaborative framework involving all stakeholders will support the hiring of ex-drugs addicts as a CSR initiative by the companies. categories hiring of ex-drug addicts as a CSR strategy and to further link it with a broader category such as social sustainability and SDGs. These policies will clarify the role of employers in hiring ex-drug addicts.

It insights the government bodies and practitioners to provide Tax exemptions for boosting the hiring of ex-drugs addicts.

Its insights practitioners for developing a collaborating framework for employing ex-drug addicts to reduce stakeholders pressure,

Table 2 summarises results based on the eleven themes of the interview transcription. The first shows the eleven themes, while the following two rows show the managerial and its subsequent insights. It presents a managerial view in hiring ex-drug addicts as CSR initiatives and the possible policy insights of the subject hiring. This study anticipates that the subjected hiring will $(a)$ improve the social sustainability rating of companies $(b)$ it will practically reduce the drug relapse, and $(c)$ it will increase compliance of the subjected companies with the global sustainable development goals.

\section{Discussions}

This study explored employers view on hiring ex-drug addicts as per the CSR initiatives in terms of the eleven themes (refer to Table 2). The subsequent section provides a discussion on results in terms of research objectives and propositions of the study. 


\section{Ml Macrothink}

\section{R01: To Understand Employers' View in Hiring Ex-Drug Addicts as Part of the CSR Initiative.}

The perception attained from respondents through the findings (refer to Table 2) alludes that hiring ex-drug addicts as part of CSR is a great initiative that is important for the country and community. It is because it reduces stigma related to ex-drug addiction from society. Even though most of the managers are yet to initiate CSR activities, but they believe it to be a noble cause and are interested in its enaction. It is perceived that CSR activities, interestingly, those managers who experienced employing ex-drug addicts, become more confident to have them on board. Those managers believe that they have seen the subjected ex-drug addict's work harder to improve their quality of life. They found them more discipline at work compared to other employees. These findings based on managerial discards past findings of Fauziah et al. (2011), which argued that the employers were reluctant to employ ex-drugs addicts. It shows that negative perception has slowly been reduced over the years, and the managers begin to gain confidence in having ex-drug addicts. Perceived findings related to the first research objectives are depicted below.
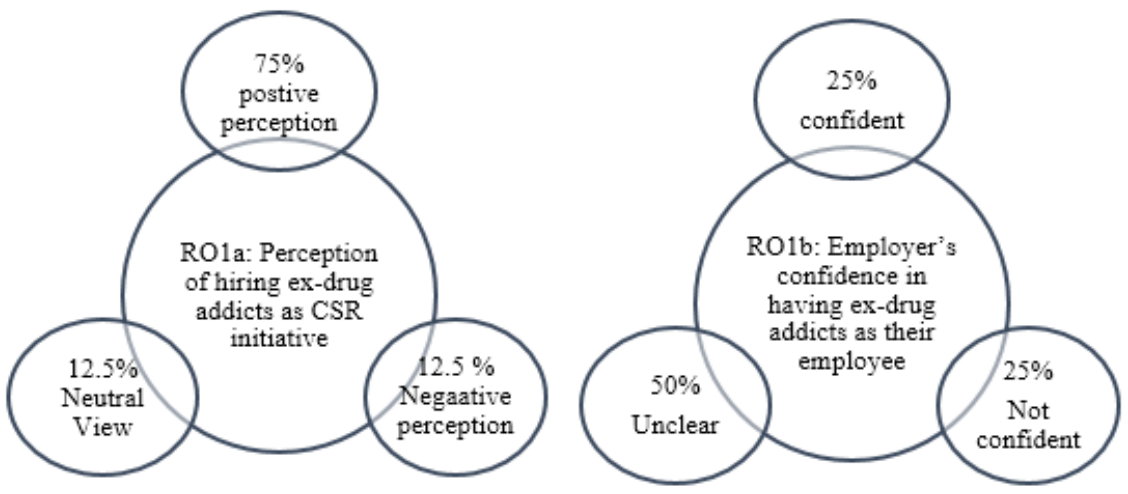

Figure 4. Percentage of Managerial View in Hiring Ex-Drug Addicts

Figure 4 shows the percentages of the managerial viewpoint in hiring ex-drugs as part of their CSR initiatives. Broadly it shows that 25 per cent of managers were confident in hiring them while 25 per cent remained unconfident. The reason behind the 50 per cent unclear view closely relates to the unavailability of a proposer framework that guides them about $(a)$ the proper process of hiring, $(b)$ its significance to the firm, $(c)$ its importance to society and $(d)$, its importance to the compliance with sustainable development goals. The proposed framework of this study (refer to Figure 2) provides those missing guidelines and motivation for hiring ex-drug addicts. Furthermore, the results showed that 75 per cent of managers possess a positive perception of hiring them. While 12.5 per cent possess a negative view and 12.5 per cent possess a neutral view. The large picture portrays that most employers possess a positive view in hiring them and are largely confident. Against that background, it rejects the initial proposition of the study, which states that,

P1: Employers show negative perception and reluctance for employing ex-drug addicts due 
to hesitation in having ex-drug addicts working in the organisation.

\section{RO2: To What Extent Employers Are Willing to Help Ex-Drug Addicts}

An organisation desire to succeed should be as great as the desire to help others (ex-drug addicts in this case). The perception attained from respondents through the findings (refer to Table 2) alludes that the employers are willing to help ex-drug addicts as long as they are talented in the related field. They believe that as long as the ex-drug addicts are capable of doing the job, the company is willing to employ them. On the other hand, few government employers mentioned that support would be given if the government designs proper policies to hire ex-drug addicts. Even though the private sector employers also possess the same view in helping ex-drug addicts only if there are clear policies by the government. It implies that the employers are awaiting some external motivation/force driving them in helping ex-drug addicts. Therefore, it can be concluded that interest or positive perception does not necessarily lead to positive actions until and unless there is great support behind the employers. The stigma around ex-drug addicts is a barrier to a wide range of opportunities. It decreases employers' confidence and self-interest. They fear that ex-drug addicts may return to their old habits of abusing drugs from their income. Therefore, a strong force and government guidelines are vital in order to provide confidence to employers while hiring ex-drug addicts. The perceived findings related to the second research objective are depicted below.

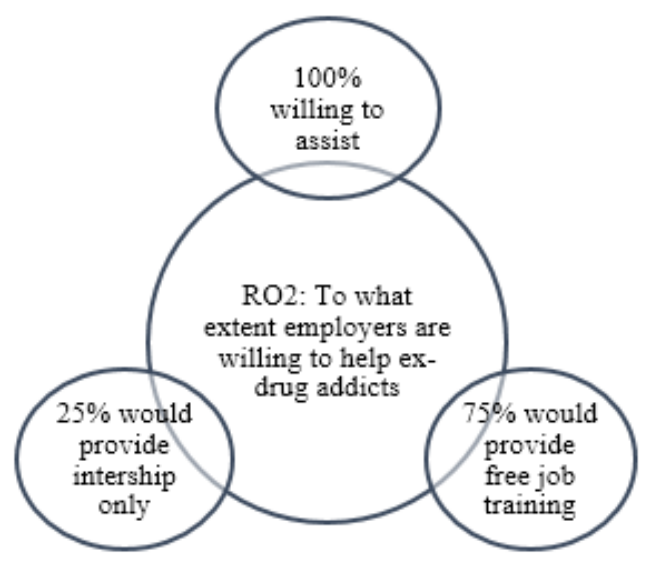

Figure 5. Percentage of Managerial willingness in helping Ex-Drug Addicts

Figure 5 depicts the percentage of employers' willingness in assisting ex-drugs addicts. It shows that 100 per cent of employers are willing to assist ex-drugs addicts. Seventy-five per cent of managers expressed that they would provide free job training. In contrast, 25 per cent argued that they would only offer internship programmes to them. It is in sighting government bodies to propose employment training schemes, which should provide good character certificates to those ex-drug addicts. It will increase the confidence of the employer towards the ex-drug addicts. Against that background, the following proposition is supported,

P2: Employers are willing to hire ex-drug addicts subjected to higher authority instruction. 


\section{Conclusion and Future Research}

This study posits an alignment between the employments of ex-drug addicts as a CSR initiative with sustainable development goals. For this purpose, this study proposed a new framework (refer to Figure 2) for aligning the CSR items with sustainable development goals. Results based on the first objective of the study illuminates that 75 percent of Malaysian employers possess a positive perception about hiring ex-drug addicts as a part of their corporate CSR strategy. However, their confidence remains low at 25 percent in the case of hiring them. It is mainly because there is a lack of availability of governmental frameworks that guides Malaysian employers about the proper procedures in hiring them. In-sighting policymakers to develop a framework by explaining a detailed recruitment process to bring organisational clarity in hiring ex-drug addicts. The framework proposed in Figure 2 can serve as a base for the required framework. Results based on the second objective shows that 100 percent of the Malaysian employers are willing to help ex-drug addicts, only a proper governmental framework is required to boost the hiring of ex-drug addicts as part of the company's CSR strategy.

\section{Direction for Future Research}

This study anticipates future studies to extend the data collecting method such as a video conference or phone interview. The scope of this study can be extended by involving more corporates in overcoming the issue of drug addicts under various CSR initiatives. The following are a few proposed areas for future research. (a), organisation's involvement in addressing drug addict employees. (b), case study on the existing organisation that is successfully implementing the employment of ex-drug addicts under CSR initiative and (c) the roles of public relations in reducing stigma and discrimination related to ex-drug addicts.

\section{Acknowledgements}

The writers would like to extend their greatest appreciation to Universiti Sains Malaysia on the funding of the Research University Grant (RUI) for the research project - Shifting Paradigm in Health Risk Communication: From Conventional to Contemporary Healthcare Communication in Modifying Behaviour. This article is one of the stated tangible outputs. The writer also acknowledges the contributions of individuals who assisted directly or indirectly towards the completion of the paper.

\section{References}

Abd Rahim, R., Jalaludin, F. W., \& Tajuddin, K. (2011). The Importance of Corporate Social Responsibility on Consumer Behaviour In Malaysia. Asian academy of management journal, $16(1)$.

Adam, F., Ahmad, W. I. W., \& Fatah, S. A. (2011). Spiritual and traditional rehabilitation modality of drug addiction in Malaysia. International Journal of Humanities and Social Science, 1(14), 175-181.

Boyce, C., \& Neale, P. (2006). Conducting in-depth interviews: A guide for designing and conducting in-depth interviews for evaluation input. 


\section{Macrothink}

Journal of Entrepreneurship and Business Innovation

ISSN 2332-8851

2021, Vol. 8, No. 2

Daymon, C., \& Holloway, I. (2010). Qualitative research methods in public relations and marketing communications: Routledge.

Dexe, J., Franke, U., \& Rad, A. (2021). Transparency and insurance professionals: a study of Swedish insurance practice attitudes and future development. The Geneva Papers on Risk and Insurance-Issues and Practice, 1-26. https://doi.org/10.1057/s41288-021-00207-9

Elkington, J. (1998). Partnerships from cannibals with forks: The triple bottom line of 21 st-century business. Environmental quality management, $8(1), \quad 37-51$. https://doi.org/10.1002/tqem.3310080106

Ali, S., Onaivi, E., Dodd, P., Cadet, J., Schenk, S., Kuhar, M., \& Koob, G. (2011). Understanding the global problem of drug addiction is a challenge for IDARS scientists. Current neuropharmacology, 9(1), 2-7. https://doi.org/10.2174/157015911795017245

Fauziah, I., Omar, M., Lukman, Z., Alavi, K., Sarnon, N., Nen, S., \& Subhi, N. (2011). Employment barriers against people with drug use histories. Pertanika Journal of Social Science and Humanities, 19, 109-114.

Freeman, R. E. (1984). Strategic Management: A stakeholder approach. Boston: Pitman. https://doi.org/10.1017/CBO9781139192675

Freeman, R. E., Wicks, A. C., \& Parmar, B. (2004). Stakeholder theory and "the corporate objective revisited". Organization science, $15(3), \quad 364-369$. https://doi.org/10.1287/orsc.1040.0066

Greenwald, M. K. (2010). Effects of experimental unemployment, employment and punishment analogs on opioid seeking and consumption in heroin-dependent volunteers. Drug and alcohol dependence, 111(1-2), 64-73. https://doi.org/10.1016/j.drugalcdep.2010.03.020

Holzer, H. J., Raphael, S., \& Stoll, M. A. (2001). Will employers hire ex-offenders? Employer checks, background checks, and their determinants. https://escholarship.org/uc/item/3c6468h2

Jan, A., \& Marimuthu, M. (2015). Bankruptcy and Sustainability: A Conceptual Review on Islamic Banking Industry. Global Business and Management Research: An International Journal, 7(1), 109-138.

Jan, A., Marimuthu, M., bin Mohd, M. P., \& Isa, M. (2019). The nexus of sustainability practices and financial performance: From the perspective of Islamic banking. Journal of Cleaner Production, 228, 703-717. https://doi.org/10.1016/j.jclepro.2019.04.208

Jan, A., Marimuthu, M., \& Hassan, R. (2019). Sustainable Business Practices and Firm's Financial Performance in Islamic Banking: Under the Moderating Role of Islamic Corporate Governance. Sustainability, 11(23), 6606. https://doi.org/10.3390/su11236606 
Jan, A., Marimuthu, M., Pisol, M., Isa, M., \& Albinsson, P. (2018). Sustainability practices and banks financial performance: a conceptual review from the islamic banking industry in Malaysia. Int. J. Bus. Manag, 13(11). doi:10.5539/ijbm.v13n11p61

Jan, A., Mata, M. N., Albinsson, P. A., Martins, J. M., Hassan, R. B., \& Mata, P. N. (2021). Alignment of Islamic Banking Sustainability Indicators with Sustainable Development Goals: Policy Recommendations for Addressing the COVID-19 Pandemic. Sustainability, 13(5), 2607. https://doi.org/10.3390/su13052607

Kamal, Y. (2021). Stakeholders expectations for CSR-related corporate governance disclosure: evidence from a developing country. Asian Review of Accounting. https://doi.org/10.1108/ARA-04-2020-0052

Khan, M. T., Khan, N. A., Ahmed, S., \& Ali, M. (2012). Corporate social responsibility (CSR)-definition, concepts and scope. Universal Journal of Management and Social Sciences, 2(7), 41-52.

Koob, G. F., \& Volkow, N. D. (2010). Neurocircuitry of addiction. Neuropsychopharmacology, 35(1), 217-238. https://doi.org/10.1038/npp.2009.110

Leukefeld, C., Webster, J. M., Staton-Tindall, M., \& Duvall, J. (2007). Employment and work among drug court clients: 12-month outcomes. Substance Use \& Misuse, 42(7), 1109-1126. https://doi.org/10.1080/10826080701409701

Lian, T. C., \& Chu, F. Y. (2013). A qualitative study on drug abuse relapse in Malaysia: contributory factors and treatment effectiveness. International Journal of Collaborative Research on Internal Medicine \& Public Health, 5(4).

Mazur, B., Cichorzewska, M., \& Mazur-Małek, M. (2020). Human oriented corporate actions: stakeholders and CSR. Organizacja $i$ Zarządzanie: kwartalnik naukowy. https://doi.org/10.29119/1899-6116.2020.50.9

Mohd, S. M. S. B. S., \& Kamarulzaman, A. (2016). Implementation of an Islamic approach to harm reduction among illicit drug users in Malaysia Islamic perspectives on science and technology (pp. 269-274): Springer. https://doi.org/10.1007/978-981-287-778-9_18

Potrikeeva, O., Suprun, N., Ispulova, S., Oleinik, E., Slepukhina, G., \& Degtyarev, A. (2017). Social rehabilitation of drug addicts in Russia: Problems of organization at the current stage and prospects for further development. Man in India, 97(11), 489-500.

Pradhan, P., Costa, L., Rybski, D., Lucht, W., \& Kropp, J. P. (2017). A systematic study of sustainable development goal (SDG) interactions. Earth's Future, 5(11), 1169-1179. https://doi.org/10.1002/2017EF000632

Sadiron, n. b. h. (2015). lived experiences in the coping and recovery process of selected drug addicts in peninsular malaysia. http://psasir.upm.edu.my/id/eprint/58236 


\section{Macrothink}

Silverman, K., Holtyn, A. F., \& Morrison, R. (2016). The therapeutic utility of employment in treating drug addiction: Science to application. Translational issues in psychological science, 2(2), 203. https://psycnet.apa.org/doi/10.1037/tps0000061

Silverman, K., Svikis, D., Wong, C. J., Hampton, J., Stitzer, M. L., \& Bigelow, G. E. (2002). A reinforcement-based therapeutic workplace for the treatment of drug abuse: three-year abstinence outcomes. Experimental and clinical psychopharmacology, 10(3), 228. https://psycnet.apa.org/doi/10.1037/1064-1297.10.3.228

Waheed, A., \& Zhang, Q. (2020). Effect of CSR and ethical practices on sustainable competitive performance: A case of emerging markets from stakeholder theory perspective. Journal of Business Ethics, 1-19. https://doi.org/10.1007/s10551-020-04679-y

Watts, P., \& Holme, R. (1999). Corporate social responsibility: Meeting changing expectations: World Business Council for Sustainable Development.

Zakaria, S. M., Jaafar, J. R., \& Lazim, N. H. M. (2018). Employment issues among ex-offenders: Difficulties in securing employment and barriers of employment. International Journal for Studies on Children, Women, Elderly and Disabled, 5, 8-12.

\section{Note}

Note 1. Formula for percentage $=$ Total respondent supporting an idea $* 100$ and divided by total number of respondent. For example, in theme 1, 07 respondent believes CSR solves social problem and hence $(7 * 100 / 8=87.5)$ 
Appendix Table A. Axial Coding Method for Categorisation and Alignment

\begin{tabular}{|c|c|c|c|c|c|}
\hline & 1: Phenomena & $\begin{array}{l}\text { 2: Causal } \\
\text { Condition }\end{array}$ & $\begin{array}{l}\text { 3: } \quad \mathrm{S} \text { intervening } \\
\text { strategies }\end{array}$ & 4: Consequences & \\
\hline Items & $\begin{array}{l}\text { Q1: How are the item and } \\
\text { category are related to each } \\
\text { other? }\end{array}$ & $\begin{array}{l}\text { Q2: How do the } \\
\text { item and category } \\
\text { influence each } \\
\text { other? }\end{array}$ & $\begin{array}{l}\text { Q3: What are the } \\
\text { actions and strategies } \\
\text { required for relating } \\
\text { items and categories? }\end{array}$ & $\begin{array}{l}\text { Q4: What are the } \\
\text { consequences of } \\
\text { relating items and } \\
\text { categories? }\end{array}$ & $\begin{array}{l}\text { Categorisation } \\
\text { and Alignment }\end{array}$ \\
\hline
\end{tabular}

Categorisation

1. Employment of ex-drug addicts as a CSR strategy

The items and category relate to each other in terms of the domain of (people-society) in the triple bottom line.

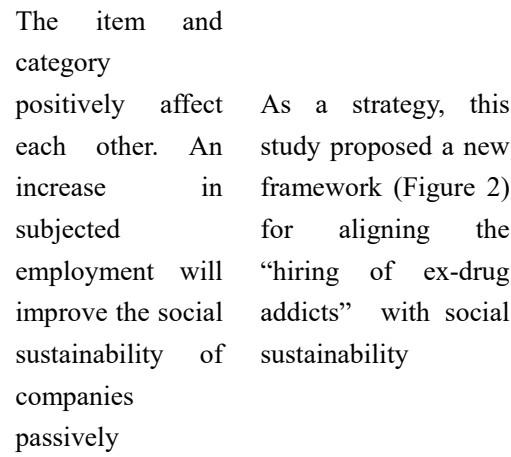

Relating the subject item with social sustainability, as a consequence will improve the social Social sustainability of Sustainability companies. And it will reduce drug relapses in society.

Alignment

2. Employment of ex-drug addicts as a CSR strategy
The subjected items are related to multiple SDGs based on philanthropic nature. This study relates the subjected item with multiple SDGs because all of these goals are interconnected. For instance, a decrease in poverty allows a person to pay for food, health and education. Furthermore, fulfilling these needs of ex-drug addicts will reduce relapses thus promoting peace.
As a strategy, this The item of "hiring ex-drugs addicts" would positively influence the subjected SDGs

\section{study proposed a new framework (Figure 2) for aligning the "hiring of ex-drug addicts" with social sustainability}

SDGs

$\begin{array}{ll}\text { Relating } & \text { the } \\ \text { subjected } & \text { item } \\ \text { with } & \text { these } 01: \text { No poverty }\end{array}$

multiple SDGs, as a consequence will increase 03: Good health compliance of and well-being companies with SDGs and hence 04: Quality will promote education sustainable development 16: Peace justice and strong institution

\section{Copyright Disclaimer}

Copyright for this article is retained by the author (s), with first publication rights granted to the journal.

This is an open-access article distributed under the terms and conditions of the Creative Commons Attribution license (http://creativecommons.org/licenses/by/4.0/). 